\title{
Patterns of Natural Revegetation In Arid Southeastern Utah
}

\author{
RICHARD A. JAYNES AND K.T. HARPER
}

\begin{abstract}
Highlight: Current and pending legislation will require that lands disturbed by mining activities be revegetated. Since few adapted species are now available for reclamation of such lands in the arid zone, this study was initiated to identify native species that are successful colonizers of disturbed sites. The native vegetation of bladed roadways in the Kane County, Utah, was sampled to identify natural colonizer species. Sixteen successful colonizers have been identified and studied to determine (1) their relative colonizing efficiency, and (2) their individual responses to elevational, soil textural, and other environmental gradients. The species fall into two natural groups: one group is well adapted to lower benchlands with sandy clay loam soils and the other is adapted to upper benchlands with sandy loam soils. Some of the species that appear to be most successful in initially revegetating disturbed areas include: (1) upper benchlands-Indian ricegrass, galleta grass, sand aster, pepperweed, broom snakeweed, smallleaf scarlet globemallow, and blue locoweed; (2) lower benchlands-shadscale, desert molly, cut-leaf globemallow, and pink locoweed.
\end{abstract}

Large deposits of low sulfur coal and oil shale occur in the arid zones of the Colorado Plateau. National needs will almost certainly require the use of all energy resources that can be mined economically. Resultant energy development operations will disrupt the natural vegetation over extensive areas of arid land. Since current and pending legislation requires that plant cover be reestablished on such lands, there is an urgent need for workable revegetation techniques for arid environments. Without some kind of stabilization treatment, mine spoils, roadsides, drill pads, and construction sites associated with energy developments will contribute significant amounts of particulate natter to the air and sediments and dissolved chemicals to surface waters in the region. The cheapest and most nearly permanent method of stabilization is likely to be revegetation with well-adapted plants. Reclamation with appropriate plant species could serve not only to restore but also to improve range productivity for wild and domestic animal life.

Although much successful revegetation work has been accomplished in portions of the West that receive over $30 \mathrm{~cm}$ of precipitation annually (Plummer et al. 1968), plant scientists have had little success in establishing permanent ground cover on disturbed sites where annual precipitation falls below $25 \mathrm{~cm}$ (Bleak et al. 1965). The current inability to establish quickly plant covers in arid zones is related to a lack of information on

Authors are research assistant and professor, Department of Botany and Range Science, Brigham Young University, Provo, Utah 84602.

Drs. J.R. Murdock, S.L. Welsh, and B.W. Woods rendered invaluable technical and logistics support without which this project would have been impossible. Holly Nicholes, Steven Spencer, and Margaret Trimble assisted in all aspects of the study. The project was supported by NSF Grant EPP75-04397. adapted species and to the unpredictability of natural precipitation.

This study was designed to sift the native flora of the benchlands of the Kaiparowits Basin, a potentially important coal field, for native species capable of naturally recolonizing disturbed sites. We also provide some information concerning ecological situations where such species might best be used.

\section{Description of Study Area}

Vegetation and associated soils were sampled on upper and lower benchlands northeast of Glen Canyon City, Utah. Soils of the upper benchland sites (ca. 1,550 m) are predominantly sandy loams derived from the Straight Cliffs sandstone formation with some localized Mancos shale influence. Soils on lower benchland sites (ca. 1,330 m) range from clay soils from tropic shale to sandy clay loams derived from Straight Cliffs or Dakota sandstone.

The study area is characterized by elements of both cold and warm desert vegetation adapted to less than $25 \mathrm{~cm}$ of mean annual precipitation. Moisture is received as winter snow, spring rain, and localized summer thunderstorms. The monthly precipitation averages form a bimodal pattern as a result of winter storms from the west and the intrusion of summer air masses from the Gulf of Mexico. Years of below-average precipitation are more frequent than above-average years. Wet winters are not always followed by wet summers, nor are dry winters necessarily followed by dry summers. Native plant species have adapted to these extreme moisture fluctuations in various ways. Annuals are abundant in the study area and flourish in wet years, but exist as seeds during drought years.

The vegetaion of the Kaiparowits Basin provides winter forage for livestock, and both habitat and forage for black tailed jackrabbits, various smaller rodents, and a variety of birds. Though sparse, the plant cover also enhances soil stability.

\section{Methods}

A total of 21 study sites was selected along roadways in shadscalegrass, blackbrush, sagebrush, and grassland-shrub communities. Roads were selected that had been graded in such a way as to remove the top 2-3 dm of soil and place it in a windrow at road edge (Fig. 1). The time since disturbance was at least 3 years, and none of the roads had received artificial surfacing materials such as petroleum stabilizers or gravel. On older roads, it proved impossible to determine accurately the length of time since disturbance, but it was obvious that each site sampled supported pioneer vegetation in the roadway and along the windrow of mixed surface soil. Three stands were selected at each site at the following locations: (1) road center where subsoil had been exposed and plants could exist without being crushed by vehicular traffic, (2) adjacent roadside berm (consisting of a mixture of subsoil and topsoil), and (3) a strip of undisturbed vegetation $10 \mathrm{~m}$ away from and parallel to the road. The three stands at each site will hereafter be referred to as subsoil, mixed soil, and undisturbed. Each stand consisted of a transect $120 \mathrm{~m}$ in length and centered on the area of 


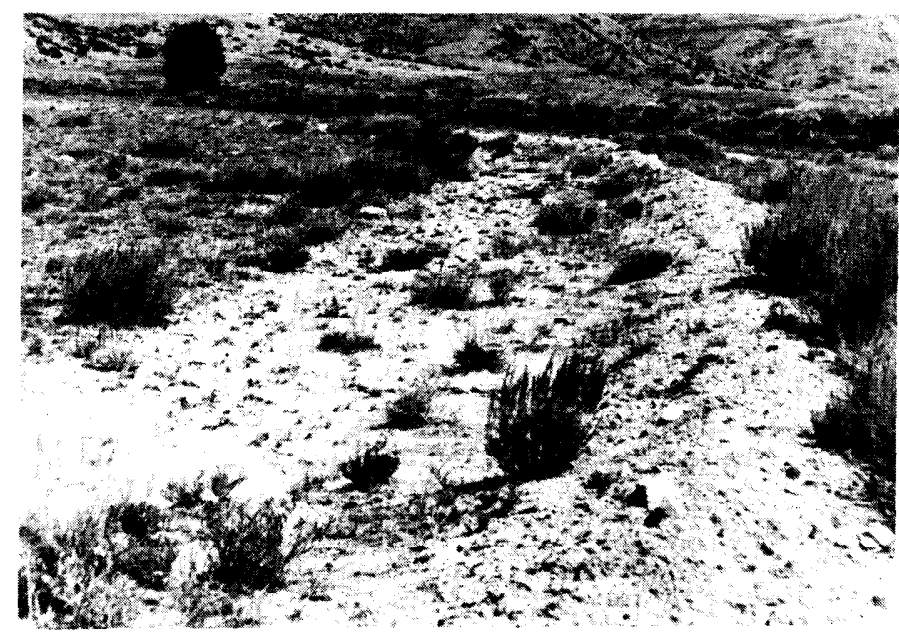

Fig. 1. Roadways had all been made by a grader or bulldozer passing over the site to clear off brush and smooth off surface irregularities. Plant debris and surface soils were windrowed into a berm at roadedge. There had been no attempt to form gutters or elevate roadbeds. Plant life persisted in the center of all roads sampled.

interest (e.g., the berm). Twenty-five quadrats $(0.25 \times 1.0 \mathrm{~m})$ were distributed along the transect at 5-meter intervals. Transects were selected for maximal topographic and edaphic homogeneity. The undisturbed stand adjacent to the roadway was viewed as being the principal seed source for colonizing species.

Vegetational data were collected in early June 1975. A checklist of all plant species occuring along each transect was made. At each quadrat, density of all perennial species rooted therein was noted and living, dead, and rock ( $\left.\geq 1 \mathrm{~cm}^{2}\right)$ cover was estimated by cover classes (Daubenmire 1968). The plant nomenclature follows Welsh and Moore (1973). A list of the most prolific colonizer species was made by selecting the species most frequently encountered on disturbed areas. The relative abundance of species was also used to help arrange the list of important colonizers

At each study area, a composite soil sample was drawn from the surface $1.5 \mathrm{dm}$. It consisted of equal quantities of soil from each transect. Soils were analyzed for texture using the hydrometer method (Foth et al. 1971).

The average frequency of each selected species was calculated for all disturbed (i.e., subsoil or mixed soil) and all undisturbed transects. Transects within each soil class were then arranged in order of decreasing frequency of the species in question. Average elevation and average $\%$ sand for transects of the top $1 / 3$ of the frequency gradient of each species were then computed and graphed.

Colonizing success of each species relative to its seed source was determined by dividing the density of each species on a disturbed area by the density of the same species in the adjacent undisturbed area and multiplying the quotient by 100 . Values exceeding 100 indicate that a species is present on disturbed areas in greater abundance than in adjacent seed source areas. Thus, this index serves as an indicator of colonization efficiency.

\section{Results and Discussion}

Information concerning general characteristics of the different vegetative types is given in Table 1. A total of 54 perennial species was observed on the 21 study areas. Sixteen of the most abundant colonizer species were selected for further study. The list includes 6 shrubs, 7 perennial forbs, and 3 grasses. The scientific and common names of those species and the general areas of their occurrence in the region are reported in Table 2 . The usual means by which each species propagates itself on the disturbed sites is also noted.

Comparative response of the 16 colonizer species along elevational and soil textural gradients is shown in Figure 2. The sandy loam soils of higher elevations are most readily colonized by Indian ricegrass, galleta grass, Fendler's threc-awn, broom snakeweed, big sagebrush, Mormon tea, sand aster, Hymenopappus, pepperweed, blue locoweed, and small-leaf scarlet globemallow. The clay loam soils of lower elevations are mainly colonized by shadscale, desert molly, budsage, pink locoweed, and cut-leaf scarlet globemallow. The rank-order of species along the elevational and soil textured gradients is highly correlated at the .01 level (Snedecor and Cochran 1967), indicating that species that prefer low elevations also do best on finer textured soils in our study area.

The arithmetical means reported in Figure 1 may be somewhat misleading, since variance around the mean is not considered. The coefficient of variation $(C . V .=$ standard deviation/arithmetic mean $\times 100$ was examined for each species. Coefficient of variation values for four species (blue locoweed, cut-leaf globemallow, galleta grass, and Indian ricegrass) are somewhat larger $(C . V .=5-11$ for elevation and $C . V .=35-39$ for soil sand), than for the other species $(C . V .=$ 1-4 for elevation and $C . V .=9-23$ for soil sand. Such results

Table 1. General environmental and vegetational characteristics associated with five vegetation units recognized in this study. Vegetational data are from the undisturbed transects at each study site.

\begin{tabular}{|c|c|c|c|c|c|c|}
\hline Vegetation type & $\begin{array}{l}\text { Average } \\
\text { elevation } \\
\text { (m) }\end{array}$ & Soil parent material & $\begin{array}{c}\text { Soil textural } \\
\text { class }\end{array}$ & $\begin{array}{l}\text { Number of } \\
\text { study areas }\end{array}$ & $\begin{array}{l}\text { Benchland } \\
\text { designation }\end{array}$ & $\begin{array}{l}\text { Average } \\
\text { living Plant } \\
\text { cover } \pm S D\end{array}$ \\
\hline Shadscale-grass & 1,310 & $\begin{array}{l}\text { Alluvium from Straight } \\
\text { Cliffs sandstone and } \\
\text { Tropic shale }\end{array}$ & $\begin{array}{l}\text { Sandy clay } \\
\text { loam }\end{array}$ & 6 & Lower & $18 \pm 5$ \\
\hline Grassland-shrub & 1,520 & $\begin{array}{l}\text { Straight Cliffs } \\
\text { sandstone residuum } \\
\text { with some localized } \\
\text { Mancos shale }\end{array}$ & Sandy loam & 5 & Upper & $26 \pm 2$ \\
\hline Spiny hopsage & 1,586 & $\begin{array}{l}\text { Straight Cliffs } \\
\text { sandstone }\end{array}$ & Sandy loam & 4 & Upper & $34 \pm 6$ \\
\hline Blackbrush & 1,582 & $\begin{array}{l}\text { Straight Cliffs } \\
\text { sandstone }\end{array}$ & Sandy loam & 4 & Upper & $20 \pm 6$ \\
\hline Sagebrush & 1,650 & $\begin{array}{l}\text { Straight Cliffs } \\
\text { sandstone }\end{array}$ & Sandy loam & 2 & Upper & $27 \pm 2$ \\
\hline
\end{tabular}



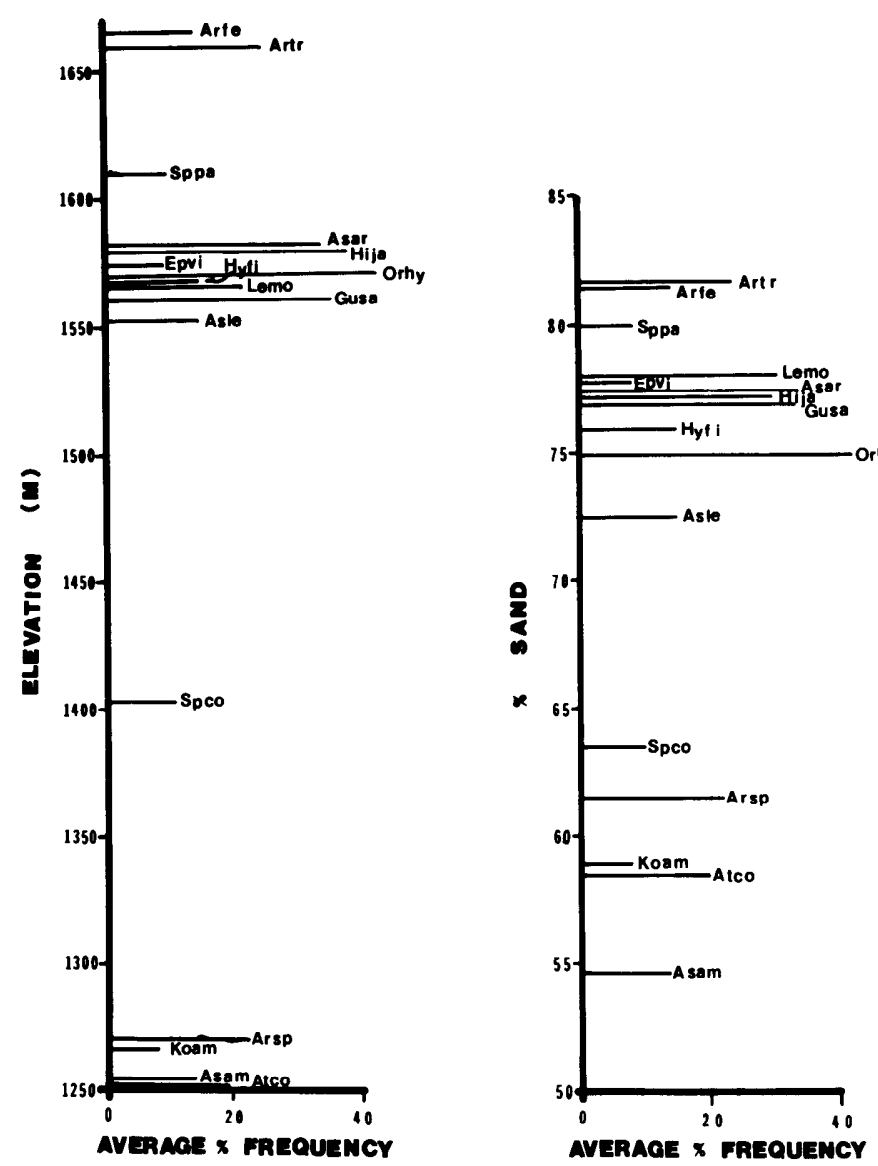

Fig. 2. Environmental conditions associated with maximal development for important colonizer species along roadedges in the Kaiparowits Basiri. Only stands from the top third of the density gradient for each species were considered in constructing this figure. Length of the horizontal line for each species indicates the average frequency of that species in quadrats placed in subsoil and mixed soil stands at the sites considered. Species abbreviations are shown in Table 2.

suggest that these four species are less restricted than the others in respect to edaphic and elevational requirements. Snakeweed occurs over a broad range of elevations; but it grows preferentially on sandy loams. Shadscale tolerates a rather broad range of soil texture, but it a vigorous colonizer only at lower elevations.

It should be noted that colonizing species of lower benchlands include few species that are capable of sprouting from roots under natural conditions (Table 2). Upper benchland areas appear to be more favorable for vegetative propagation, since several species there (especially forbs) reproduce vegetatively following disturbance.

The performance of the various species on disturbed and undisturbed areas can be uscd to compute a useful measure of the relative ability of each to colonize newly opened sites from a parental population of standardized size. The species are ranked according to colonization success on subsoil and mixed soil sites in Fig. 3. Broom snakeweed, Indian ricegrass, both scarlet globemallows, and both locoweed species appear to be among the more efficient colonizers of disturbed areas (i.e., they were found in greater abundance on the disturbed sites than in the adjacent source area.) Sand aster and Hymenopapus also do well on both kinds of disturbed sites. Part of the success of the latter two species may be due to their ability to reproduce vegetatively from plant parts buried so deeply that they escape destruction in

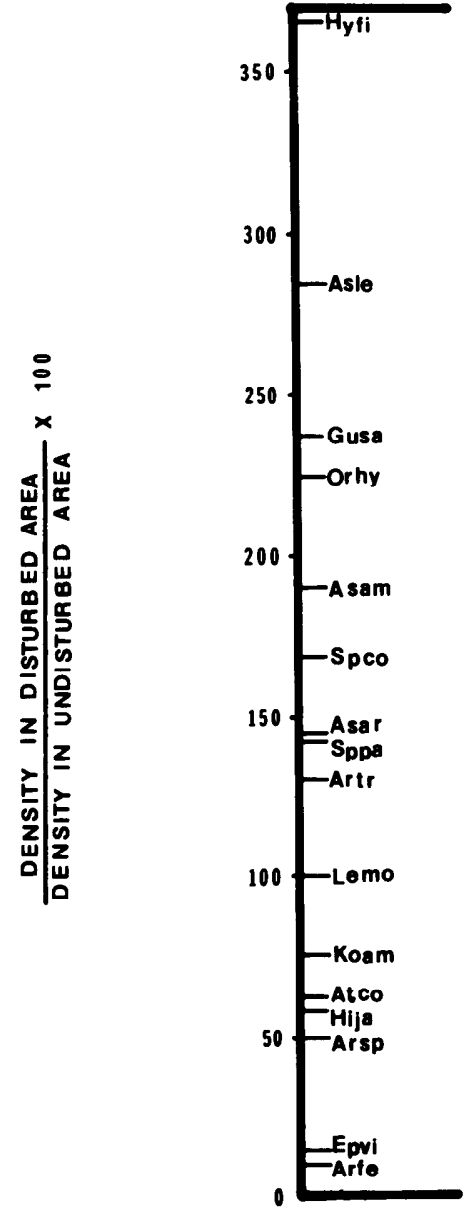

Fig. 3. Relative success of the species as colonizers. Species unable to persist in disturbed sites would have a value of zero; a value of 100 indicates that the species is as abundant in the disturbed as in the undisturbed area. The horizontal scale has no meaning. Abbreviations are as in Table 2. The vertical axis is identical for subsoil and mixed soil.

the process of road construction. Again, it is apparent that the upper benchlands represent a more favorable environment for plant growth, since most of the highly efficient colonizers are found there.

Most of the species considered perform better on the mixed soil berm than the scraped roadbed (Fig. 2), but three species reach maximum density in the road itself (sand aster, small-leaf globemallow, and galleta grass). Performance of those species appears to be hampered by competition from associated species on less disturbed sites.

Stepwise multiple variable regression analyses of environmental factors controlling the performance of species selected as good colonizers have been performed. These analyses are based on data for 72 undisturbed sites from a study by Jaynes (1976) which was conducted in the same area utilized for this study. Environmental variables considered in the analyses include soil texture, salinity, $\mathrm{pH}$, and stoniness, water infiltration rates, and microtopography (elevation, aspect and \% slope). Frequency of species occurrence was used as the dependent variable. Results are reported in Table 3. Multivariate equations are helpful in predicting species response to selected variables, but they had limited value as predictors of relative colonizer success on denuded sites in this study. The rather low $R^{2}$-values would have been improved by increasing 


\begin{tabular}{|c|c|c|c|c|c|}
\hline Scientific name & Common name & Symbol & $\begin{array}{l}\text { Community of } \\
\text { best development }\end{array}$ & $\begin{array}{l}\text { Benchland } \\
\text { of best } \\
\text { development }\end{array}$ & $\begin{array}{l}\text { Commonest means of } \\
\text { propagation on } \\
\text { disturbed sites }\end{array}$ \\
\hline \multicolumn{6}{|l|}{ Shrubs } \\
\hline Artemisia spinescens & Budsage & Arsp & Shadscale & Lower & seed \\
\hline Artemisia tridentata & Big sagebrush & Artr & Sagebrush & Upper & seed \\
\hline Artiplex confertifolia & Shadscale & Atco & Shadscale & Lower & seed \\
\hline Ephedra viridis & Mormon tea & Epvi & $\begin{array}{l}\text { Grassland-shrub } \\
\text { and spiny hopsage }\end{array}$ & Upper & seed, root? \\
\hline Gutierrezia sarothrae & Broom snakeweed & Gusa & Shadscale & Upper & seed, root? \\
\hline Kochia americana & Desert molly & Koam & Shadscale & Lower & $\begin{array}{l}\text { seed, some } \\
\text { rhizome }\end{array}$ \\
\hline \multicolumn{6}{|l|}{ Forbs } \\
\hline Astragalus amphioxys & Pink locoweed & Asam & Shadscale & Lower & seed \\
\hline Astragalus lentiginosus & Blue locoweed & Asle & $\begin{array}{l}\text { Grassland-shrub } \\
\text { and blackbrush }\end{array}$ & Upper & seed \\
\hline Aster arenosus & Sand aster & Asar & Sagebrush & Upper & seed, thizome \\
\hline Hymenopappus filifolius & Hymenopappus & Hyfi & Grassland-shrub & Upper & seed, root? \\
\hline Lepidium montanum & Pepperweed & Lemo & Blackbrush & Upper & seed \\
\hline Sphaeralcea coccinia & $\begin{array}{l}\text { Cut-leaf scarlet } \\
\text { globemallow }\end{array}$ & Spco & Shadscale & Lower & seed \\
\hline Sphaeralcea parvifolia & $\begin{array}{l}\text { Small-leaf scarlet } \\
\text { globemallow }\end{array}$ & Sppa & Grassland-shrub & Upper & seed, root? \\
\hline \multicolumn{6}{|l|}{ Grasses } \\
\hline Aristida fendleriana & Fendler's three-awn & Arfe & Grassland-shrub & Upper & seed \\
\hline Hilaria jamesii & Galleta grass & Hija & $\begin{array}{l}\text { Grassland-shrub } \\
\text { and spiny hopsage }\end{array}$ & Both & seed, rhizome \\
\hline Oryzopsis hymenoides & Indian ricegrass & Orhy & $\begin{array}{l}\text { Grassland-shrub } \\
\text { and spiny hopsage }\end{array}$ & Both & seed \\
\hline
\end{tabular}

the range of variation encountered in species success in the stands studied (e.g., including disturbed sites where species are colonizing). Nevertheless, the equations do provide useful information concerning the ecology of species which may have value in revegetation programs (Wikum and Wali 1974).

Some of the species found growing on disturbed sites in this study had apparently not become established by seed but had survived disturbance by sprouting from the crown or from rhizomes (e.g., both globemallow species, pepperweed, galleta grass, and Mormon tea). Since the ability of plants to persist on harsh sites is an important characteristic of good colonizing species, we have made no distinction between plants occurring

Table 3. Multivariate regression equations for colonizer species. The dependent variable in all cases was \% frequency of each species.

\begin{tabular}{|c|c|c|c|c|}
\hline & $\begin{array}{l}\text { Number of } \\
\text { study sites } \\
\text { of occurrence }\end{array}$ & $\begin{array}{l}\text { Regression equation* } \\
\mathrm{y}=\text { the percent frequency of each species in } 0.25 \mathrm{~m}^{2} \text { quadrats }\end{array}$ & $R^{2}$ & Significance \\
\hline \multicolumn{5}{|l|}{ Shrubs } \\
\hline Artemisia spinescens & 21 & $y=11.1-.07 E+.01 S a+.61 \% S 1-.39 S D-.41 R+3.18 S P$ & .42 & n.s. \\
\hline Atriplex confertifolia & 45 & $\mathrm{y}=53.6-.07 \mathrm{E}-.79 \mathrm{C}+10.90 \mathrm{Ex}+10.17 \mathrm{pH}-.27 \mathrm{IR}+.0009 \mathrm{SA}$ & .35 & .025 \\
\hline Ephedra viridis & 57 & $y=-45.2-.38 R+.04 E-4.50 S P+.24 S+.18 I R-3.77 E x$ & .46 & .005 \\
\hline Gutierrezia sarothrae & 63 & $y=-151.5+.50 S+.08 E-.24 I R+.47 S D+.63 R+3.78 S P$ & .48 & .005 \\
\hline Kochia americana & 15 & $\mathrm{y}=44.8+1.73 \mathrm{C}-13.72 \mathrm{EX}-.05 \mathrm{E}+.22 \mathrm{IR}$ & .81 & .005 \\
\hline \multicolumn{5}{|l|}{ Forbs } \\
\hline Aster arenosus & 47 & $y=-50.1-6.1 E x+8.1 p H-.10 I R+.0850$ & .22 & .05 \\
\hline Astragalus amphioxys & 63 & $y=63.1-6.18 \mathrm{pH}-.0008 \mathrm{Sa}+.06 \mathrm{SD}+1.60 \mathrm{Ex}-.008 \mathrm{E}$ & .16 & n.s. \\
\hline Astragalus lentiginosus & 29 & $y=105.5-.04 E-5.4 p H-.003 S a$ & .61 & .005 \\
\hline Lepidium montanum & 48 & $y=158.8+11.73 \mathrm{Ex}-23.63 \mathrm{pH}+.05 \mathrm{E}-.01 \mathrm{Sa}-.36 \mathrm{~S}-.11 \mathrm{SD}$ & .48 & .005 \\
\hline Sphaeralcea coccinea & 45 & $\mathrm{y}=15.8-.06 \mathrm{SD}+.002 \mathrm{SA}-1.12 \mathrm{Ex}-1.20 \mathrm{pH}-.41 \mathrm{SP}$ & .38 & .005 \\
\hline Sphaeralcea parvifolia & 33 & $\mathrm{y}=122.9-.53 \mathrm{C}-.38 \mathrm{R}-12.41 \mathrm{pH}-.04 \mathrm{Sa}$ & .27 & n.s. \\
\hline \multicolumn{5}{|l|}{ Grasses } \\
\hline Aristida fendleriana & 30 & $y=0.2+.28 \mathrm{SD}-.007 \mathrm{Sa}-.12 \mathrm{IR}$ & .44 & .005 \\
\hline Hilaria jamesii & 70 & $y=264.5-2.32 C+9.52 S P-.89 S-1.66 \% S l-.08 E-.66 R$ & .40 & .005 \\
\hline Oryzopsis hymenoides & 70 & $y=86.8+6.47 S P-.97 \% S 1-.23 C+.16 S D-9.41 p H$ & .19 & .025 \\
\hline
\end{tabular}

Vuriables are arranged in the sequence of their entry into the stepwise regression.

Key to symbols used:

$\begin{array}{ll}\mathrm{C}=\% \text { Clay } & \mathrm{SP}=\text { slope position }(\text { top }=1, \text { middle }=2, \text { bottom }=3) \\ \mathrm{S}=\% \text { sand } & \mathrm{SD}=\text { soil depth }(\mathrm{cm}) \\ \% \mathrm{SI}=\text { slope } & \mathrm{EX}=\text { exposure }(2.00=\text { Northeast, } 0.00=\text { Southwest }) \\ \mathrm{E}=\text { elevation }(\mathrm{m}) & \mathrm{Sa}=\text { soil salinity }(\mathrm{ppm}) \\ \mathrm{R}=\% \text { soil rock } & \mathrm{pH}=\operatorname{soil} \mathrm{pH}(1: 1 \mathrm{soil} / \mathrm{water} \text { paste }) \\ & \mathrm{IR}=\text { infiltration rate }(\mathrm{cm} / \mathrm{min})\end{array}$


on a disturbed site as a consequence of seedling establishment or resprouting. From our field observations, however, the majority of the species considered to be effective colonizers apparently had invaded by seed.

Some of the candidate species noted have undesirable forage properties (e.g., snakeweed and locoweed). Where vegetative cover is the main goal, unpalatability may become a secondary consideration. Along roadsides where grazing animals present traffic hazards, unpalatable plants may actually be desirable.

Species such as sand dropseed (Sporoholus cryptandrus) and squirreltail (Sitanion hystrix) have been recommended for inclusion in seeding mixtures for sandy, arid sites (Plummer et al. 1955). Although these species were often present in undisturbed communities adjacent to our disturbed plots, they were not good colonizers for our roadways.

The existing flora of the Kaiparowits Basin is a valuable source of adapted species for land reclamation projects on the Colorado Plateau, but not necessarily the only group of plants that should be considered. Some introduced perennial and annual species may also play important roles in future reclamation projects.

\section{Literature Cited}

Bleak, A.T., N.C. Frischknecht, A.P. Plummer, and R.E. Eckert, Jr. 1965. Problems in artificial and natural revegetation of the arid shadscale vegetation zone of Utah and Nevada. J. Range Manage. 18:59-65.

Daubenmire, R.F. 1959. A canopy-coverage method of vegetational analysis. Northw. Sci. 33:43-64.

Foth, H.D., H.S. Jacobs, and L.V. Withee. 1971. Laboratory manual for introductory soil science, 3rd ed. Wm. C. Brown, Co. 104 p.

Jaynes, R.A. 1976. Effects of selected edaphic and topographic factors on plant communities of southwestern benchlands. Paper Presented at Society for Range Management Annual Meeting, February 1976. Omaha, Nebraska.

Plummer, A.P., D.R. Christensen, and S. B. Monson. 1968. Restoring big game range in Utah. Utah Fish and Game Pub. No. 68-3.

Plummer, A.P., A.C. Hull, Jr., G. Stewart, and J.H. Robertson. 1955. Seeding rangelands in Utah, Nevada, southern Idaho, and western Wyoming. U.S. Dep. Agr. Hand. 71 .

Snedecor, G.W., and Cochran, W.G. 1967. Statistical methods, 6th ed. Iowa State Univ. Press, Ames.

Welsh, S.L., and G. Moore, 1973. Utah plants: Tracheophyta, 3rd ed. Brigham Young University Press. Provo, Utah.

Wikum, D.A., and M.K. Wali. 1974. Analysis of a North Dakota gallery forest: vegetation in relation to topographic and soil gradients. Ecol. Monogr. $44: 441-464$.

\title{
Introduction to Renewable Resource Inventory Methods
}

\author{
Short course/March 5-9, 1979 \\ Berkeley, California
}

Development of integrated sampling and measurement systems using aerial photographs and satellite and ground data.

Application deadline: February 2, 1979. For information: Write to Letters and Sciences, Dept. S-9, UC Extension, 2223 Fulton St., Berkeley, CA 94720. Or call (415) 642-1061.

Presented by:

University of California, Berkeley, and the EROS Data Center, USGS 